Revista Española de Antropología Americana ISSN: 0556-6533

https://doi.org/10.5209/reaa.66527

\title{
El tacto y la interacción en el arte maya antiguo
}

\author{
Megan E. O’Neil ${ }^{1}$
}

Recibido: 5 de marzo de 2019 / Aceptado: 14 de julio de 2019

Resumen. Este Dossier sobre iconografía maya enfatiza la importancia de estudiar las imágenes mayas antiguas en relación con tres ejes analíticos: el soporte material, el contexto físico y el contexto histórico. Este ensayo añade un cuarto eje analítico: la experiencia que las personas tenían con las artes plásticas, especialmente con los medios esculpidos. Para seguir este camino, el ensayo investiga la importancia del tacto y la interacción en el arte maya antiguo. La experiencia somática de las imágenes, los objetos y los edificios tuvieron que ser una parte crucial de su significación y valoración estética. A partir de ello, el artículo se enfoca en la experiencia física que las personas -artistas o usuarios- tuvieron con los materiales y las obras. Se centra en dos estudios diferentes: los pequeños implementos de hueso del Entierro 116 de Tikal (Guatemala) y las esculturas monumentales de piedra de Piedras Negras (Guatemala). Las investigaciones tratan de reconstruir los contextos materiales e investigar cómo las imágenes e inscripciones se relacionan tanto con los soportes materiales como con los lugares donde fueron erigidos, usados o depositados. Estos estudios revelan cómo los artistas mayas fomentaron el tacto, el movimiento y otras interacciones, y cómo estas acciones podrían haber funcionado como experiencias rituales.

Palabras clave: arte maya; iconografía; experiencia; tacto; vidas sensoriales.

\section{[en] Touch and Interaction in Ancient Maya Art}

\begin{abstract}
This dossier about Maya iconography emphasizes the importance of studying ancient Maya images in relation to three analytical axes: material support, physical context, and historical context. This essay adds a fourth analytical axis: the experience that people had with works of art, especially with sculpted media. To follow this path, the essay investigates the importance of touch and interaction in ancient Maya art. The somatic experience of images, objects, and buildings was a crucial part of their significance and aesthetic valuation. To these ends, the article focuses on the physical experience that people - artists or users - had with the materials and works. It focuses on two case studies: the small bone implements from Burial 116 of Tikal (Guatemala) and the monumental stone sculptures of Piedras Negras (Guatemala). This research seeks to reconstruct their material contexts and to investigate how the images and texts relate both to the material supports and the places where they were erected, used, or deposited. These studies reveal how Maya artists fostered touch, movement, and other interactions and how these actions could have functioned as ritual experiences.
\end{abstract}

Keywords: Maya art; iconography: experience; touch; sensory lives.

Sumario. 1. Introducción. 2. La interacción y el tacto en las imágenes mayas. 3. La importancia de las manos en el arte y ritual maya. 4. Interacción con los objetos y monumentos: los huesos tallados de Tikal. 5. Interacción con los monumentos y objetos: las esculturas de Piedras Negras. 6. Conclusiones. 7. Referencias.

\footnotetext{
1 Profesora, Emory University, y conservadora en el Michael. C. Carlos Museum de la Emory University, Estados Unidos.moneil7@emory.edu.
} 
Cómo citar: O’Neil, Megan E. 2019. «El tacto y la interacción en el arte maya antiguo». Revista Española de Antropología Americana 49: 173-191.

\section{Introducción}

En el módulo de información turística del Parque Nacional de Tikal (Petén, Guatemala), se encuentran pintadas las imágenes de dos cautivos de pie en los extremos de una canoa (Figura 1). Estas imágenes provienen de dos huesos tallados que fueron depositados en la ofrenda funeraria del Entierro 116 de Tikal, la tumba del rey Jasaw Chan K'awiil (734 d.C.) $)^{2}$. Uno de los huesos de la ofrenda muestra una canoa que lleva al dios del maíz y a unos animales mitológicos por las aguas del inframundo, en un viaje a través del cual esta deidad y el citado rey renacerán. El otro hueso representa un cautivo que mira sus manos atadas con angustia (Figura $2 b)^{3}$.

Los originales son pequeños objetos que uno puede manipular con las manos, pero en el módulo de información están representados con un tamaño aumentado. El artista moderno tomó así las miniaturas y las hizo monumentales, perdiendo la escala original. También combinó las imágenes y textos de dos objetos en una sola composición y los aplanó, poniendo las imágenes y los textos de varios lados de los objetos tridimensionales en una sola composición. Así perdió la forma de los implementos originales, las relaciones entre texto e imagen, y la manera en que las imágenes siguen las formas naturales de los huesos. Por eso, las imágenes se desvinculan de sus soportes materiales antiguos y los modos en que las personas hubieran podido experimentar los objetos.

Por supuesto, no se trata de criticar esta pintura porque es una imagen creada para atraer la atención de los turistas hacia el sitio arqueológico. Sin embargo, los dibujos que el artista moderno usó provienen de los dibujos de una publicación arqueológica, hechos por Annemarie (Andy) Seuffert, la excelente dibujante del Proyecto Arqueológico Tikal del Museo de la Universidad de Pennsylvania, y publicados por Aubrey Trik (1963). Desde 1963, estos dibujos han sido retomados por numerosos académicos en sus publicaciones. Los dibujos son claros y legibles y, debido a la condición de los huesos cuando fueron encontrados, son necesarios para mostrar el contenido de las imágenes y textos. Sin embargo, las líneas aplanan los diseños, que en los originales se envuelven alrededor de los huesos, invitando al usuario a girarlos para poder apreciarlos en su totalidad (Figura 2a-b). Los dibujos no permiten notar adecuadamente las acciones requeridas para verlos y experimentarlos. La academia ha dependido de estos dibujos para el estudio de la iconografía, pero se ha olvidado del estudio de la materialidad y la experiencia de los objetos.

Ana García Barrios y Daniel Salazar Lama, coordinadores de este Dossier de la Revista Española de Antropología Americana (REAA) sobre iconografía maya,

\footnotetext{
Alrededor del cuerpo del rey había perlas, jade, conchas y vasijas de cerámica. En el suelo había más vasijas y un depósito de huesos tallados. Estos huesos se encontraron muy fragmentados; Aubrey Trik y William Coe calcularon que había unas 90 piezas, incluyendo punzones, espátulas e instrumentos musicales (Trik 1963; Coe 1990). El Tikal Project identificó huesos del venado de cola blanca, ciervo no especificado, jaguar y pájaro no especificado (Moholy-Nagy y Coe 2008: 61). Se necesitan pruebas adicionales para identificar las especies de los otros huesos.

3 MT39A y MT39B son dos huesos tallados con imágenes de cautivos que forman un par con las imágenes de espejo. Sin embargo, para la composición moderna, el pintor pintó dos veces el diseño de MT 39B. Invirtió uno para conservar la simetría, pero resulta que una inscripción está al revés.
} 


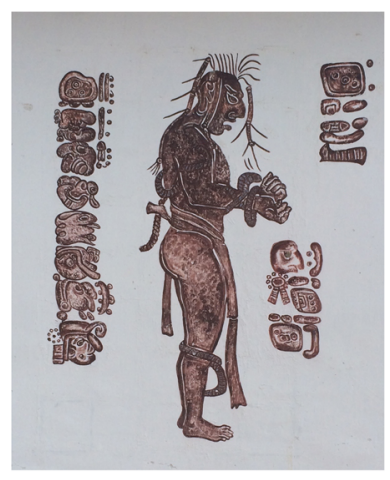

a

Figura 1. Módulo de información turística del Parque Nacional de Tikal, Guatemala: a) detalle del cautivo a la izquierda (con inscripciones al revés);

b) la canoa y los dos cautivos (fotografía de la autora, 2015).

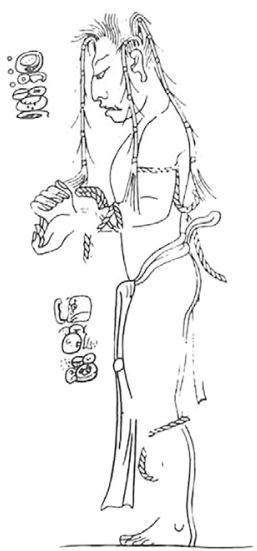

a

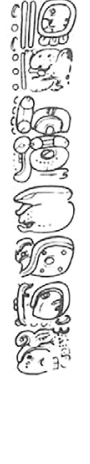

Figura 2. Tikal, Guatemala, Entierro 116: Hueso tallado con cautivo, c. 734 d.C. 4P113(38), MT 39A. a) Cara anterior (dibujo de Annemarie Seuffert, en Trik 1963: Fig. 9a, b); b) cara posterior (fotografías de William Coe, CX-63-4-87, 63-4-376. Cortesía de University of Pennsylvania Museum of Archaeology and Anthropology). 
enfatizan la importancia de estudiar las imágenes mayas antiguas con relación a tres ejes analíticos: el soporte material, el contexto físico y el contexto histórico. Este tipo de estudio multidimensional es un enfoque esencial en mis propios estudios del arte maya, pero quisiera añadir un cuarto eje analítico: la experiencia que las personas tenían con las artes plásticas. Para seguir este camino, quisiera investigar la importancia del tacto y la interacción en el arte maya antiguo, especialmente en los medios esculpidos. La historia del arte se enfoca mucho en la visión, en lo que se ve, para llegar al significado de la pieza o la intención del artista. Sin embargo, la experiencia somática de las imágenes, de los objetos y de los edificios tuvo que ser una parte crucial de su significado y valoración estética. Para estos fines, quisiera enfocarme en la experiencia física o somática que las personas — artistas o usuariostuvieron con los materiales y las obras.

Este ensayo se centra en dos casos de estudio: los pequeños utensilios de hueso del Entierro 116 de Tikal y las esculturas monumentales de piedra de Piedras Negras (Petén, Guatemala). En mi investigación trato de reconstruir los contextos materiales, así como el dónde y el cómo las obras estuvieron elaboradas, tanto en relación con los soportes materiales como con los lugares donde fueron erigidos, usados o depositados. Examino además cómo de hecho los contextos físicos de las imágenes mayas eran vitales en las artes escultóricas. Estos estudios revelan cómo los artistas mayas fomentaron el tacto, el movimiento y otras interacciones, y cómo estas acciones pudieron haber funcionado como experiencias rituales. Estos estudios están basados en la exploración de la experiencia del cuerpo humano con los materiales y por lo tanto están relacionados con la fenomenología y los estudios de la materialidad. Como Lynn Meskell (2004: 249) escribió sobre el arte egipcio antiguo: «Studies of materiality cannot simply focus upon the characteristics of objects but must engage in the dialectic of people and things». Además, estos estudios están íntimamente relacionados con la iconografía, porque las imágenes, formas y materiales de una obra funcionaban juntos para los artistas y usuarios mayas, y por lo tanto deberíamos considerar sus obras de una manera holística.

La publicación de la imagen fuera de su soporte material es particularmente común en los estudios de la iconografía maya. El uso de los dibujos lineales se ha convertido en una forma estándar para publicar las obras mayas antiguas, porque es una manera de simplificar las imágenes complejas o de mostrar los detalles. Además, la publicación en forma de dibujo por ejemplo, de los huesos tallados de Tikal y de las esculturas de Piedras Negras, es también necesaria debido a la condición de estas piezas. En particular, los huesos de Tikal ya estaban muy deteriorados en el momento de su descubrimiento en 1962 (Trik 1963). Por el contrario, a mediados del siglo $\mathrm{XX}$, muchos monumentos de Piedras Negras fueron cortados, saqueados y dispersados alrededor del mundo (O'Neil 2012: 189-211). Los dibujos lineales muestran estas obras en una manera completa y clara, permitiendo que nos enfoquemos en la comprensión de sus imágenes y en el desciframiento de sus inscripciones. No obstante, la claridad viene con un gran sacrificio, pues se pierde la tridimensionalidad y la dimensión física del objeto. Estas ilustraciones desmaterializan las imágenes, haciéndonos olvidar sus formas materiales. También oscurecen las conexiones fundamentales que los artistas tenían con los materiales y sus modos de fabricación, ignorando así las experiencias de los usuarios.

La experiencia es un asunto difícil de reconstruir, especialmente después de más de mil años. La sutileza de la experiencia sensorial quizás nunca podría ser enten- 
dida, pero podemos intentar acercarnos a la esfera de la experiencia estudiando las obras mismas, los entornos físicos y la evidencia material del uso y de los usuarios. De hecho, tenemos indicios de lo que podría haber estimulado los sentidos, ya sea visión, oído, tacto, gusto u olfato. Hay inscripciones e imágenes antiguas que comunican información sobre los sentidos (Houston y Taube 2000). Además, hay trazas de hollín sobre las estelas, los altares y las paredes de los santuarios que se han conservado de las ceremonias de fuego que habrían emitido calor y olores de sustancias como pino y copal. Las pinturas que representan músicos tocando instrumentos y los ejemplos de innumerables silbatos y ocarinas encontrados en tumbas y ofrendas nos permiten imaginar los sonidos de la música en las ceremonias.

Pensar en el tacto y la interacción es una manera de tratar de reconstruir las «vidas sensoriales» en el pasado, un tema que Ruth Van Dyke (2012) ha abordado sobre la cultura Chaco en el suroeste estadounidense. Enfocándose en las vidas sensoriales recuerda que no podemos entender el tacto aislado de los otros sentidos, porque un usuario antiguo habría experimentado las artes plásticas a través de múltiples sentidos. Otros autores han examinado el sentido del tacto como parte de la experiencia de las obras de arte. Elizabeth Edwards (1999) considera el tacto como uno de los varios sentidos usados en la experiencia de las fotografías. Además, la visión y el tacto se complementan. Investigando de manera más general la percepción humana, Maurice Merleau-Ponty (2002: 262) describe que los sentidos son complementarios y se comunican entre sí. Teoriza el concepto de la síntesis o la unidad de los sentidos, en la cual dos o más sentidos -simultáneamente- permiten al usuario experimentar una sensación más plenamente, y observa que la vista y el tacto son necesarios para percibir enteramente una pieza hecha (ibíd.: 268). Aunque las cosas y los espacios pueden ser experimentados a través del tacto solamente, la visión generalmente se comunica directamente con el tacto. El autor explora la idea de que el área experimentada por el tacto está más limitada al espacio inmediato del cuerpo, pero la vista como un sentido complementario permite aumentar el campo perceptivo que se puede experimentar simultáneamente (ibid.: 259-260). La complementariedad de estos sentidos es crucial para la experiencia.

Es claro que para los artistas mayas antiguos era relevante una complementariedad análoga, y que estaban conscientes de la experiencia de los sentidos múltiples en conjunto. Vemos esto en la manera con la que solucionaron formas que no podían ser entendidas sólo con la vista, para las que se requería algún tipo de movimiento o acción, como la circunvalación de un monumento o el giro de una pieza, para ver o tocar el resto de la imagen y la obra completa y para llegar a una mejor comprensión. En realidad, quizás la intención fue inspirar al usuario a mover o a usar otros sentidos ya que tales movimientos y acciones crean una experiencia ritual eficaz.

Stephen Houston y Karl Taube (2000) han discutido el tema de percepciones multisensoriales, enfocándose particularmente en la visión, el oído y el olfato. Por ejemplo, muestran como los mayas antiguos y otras culturas mesoamericanas usaban elementos visuales, como las volutas del habla -que son accesibles por vista- para invocar el olfato y el oído. Llaman a estos elementos «ingenious synaesthetic codes» (ibid.: 289). Comparativamente, considero que los artistas mayas enfatizaban las representaciones de las manos y los dedos agarrando y tocando los objetos. Era un mecanismo visual dirigido al sentido de la vista para invocar al sentido del tacto en la persona que lo veía, produciendo una experiencia somática más compleja. 

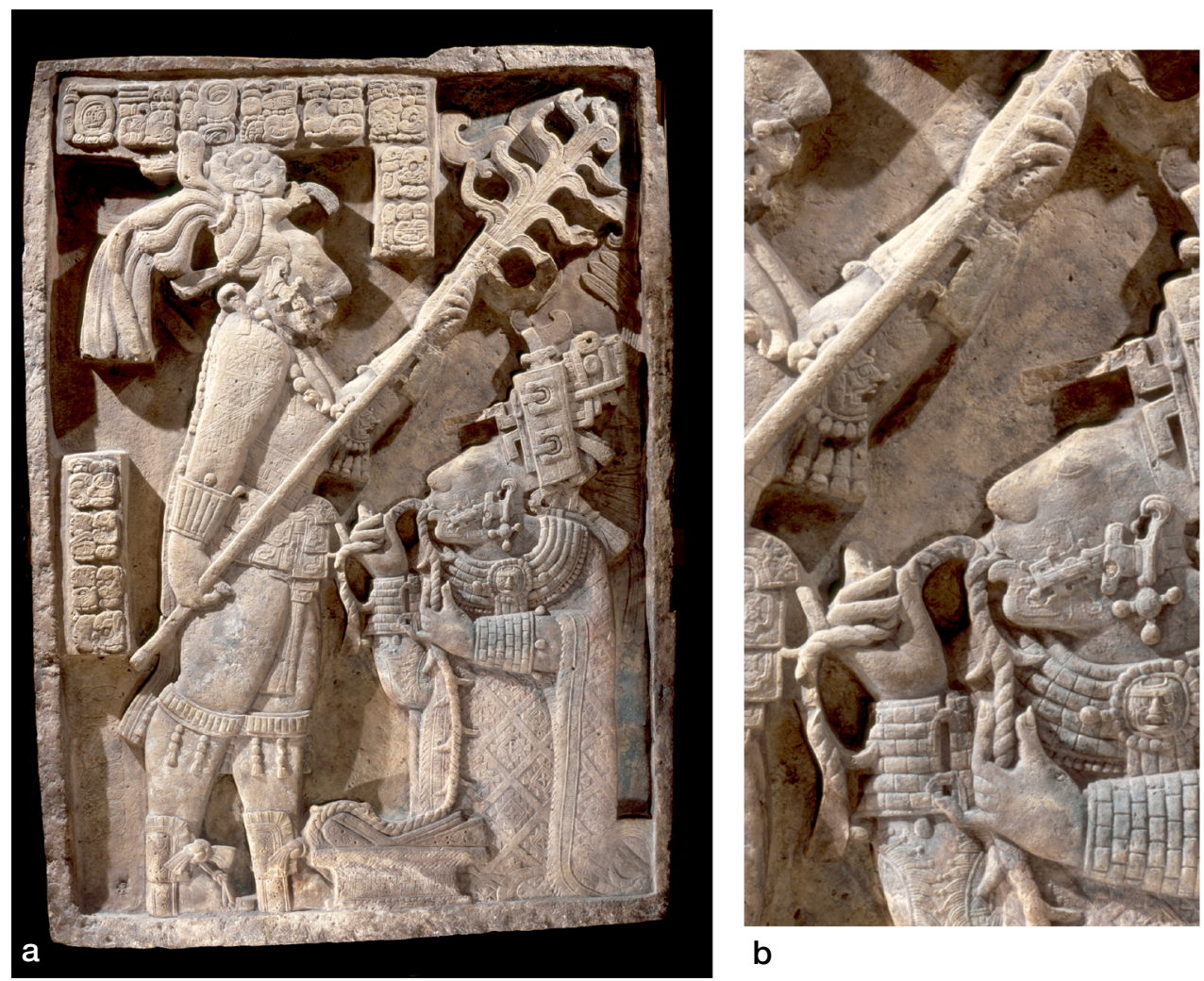

Figura 3. Dintel 24 de Yaxchilán, Chiapas, México: a) dintel completo (cortesía del British Museum); b) detalle (fotografía (C) Justin Kerr).

\section{La interacción y el tacto en las imágenes mayas}

Muchas imágenes mayas antiguas transmiten la importancia de la interacción, el movimiento y el tacto en el arte, la religión y la política maya. De hecho, hay una atención significativa al sentido del tacto en muchos aspectos del arte y la escritura. Al mismo tiempo, se pone atención a la importancia de la interacción entre personas y objetos. Por ejemplo, hay muchas imágenes donde las figuras interactúan, ya sean dos seres humanos - madre e hijo, rey y reina, rey y cautivo-o de un ser humano y otro sobrenatural, ya sea dios o antepasado. También es común retratar a las personas que tocan los objetos rituales. Por ejemplo, el Dintel 24 de Yaxchilán (Chiapas, México) retrata al rey Itzamnaaj Bahlam y a la reina Ixik K'abal Xook mientras enfrentados entre sí- realizan una ceremonia en la que el rey sostiene una antorcha mientras la reina perfora su lengua para derramar sangre en la fecha en que el rey ascendió al trono. Sus acciones y su interacción son importantes (Figura 3). No es el individuo aislado, sino que es su interacción la que describe la narrativa. Además, el sentido del tacto está acentuado en la escena. En particular, los artistas pusieron atención en la elaboración de las manos agarrando objetos. Cada mano de Itzamnaaj Bahlam rodea con firmeza el mango de la antorcha, mientras que las manos de Ixik K'abal Xook agarran la cuerda. Las curvas de los dedos alrededor de los materiales 
Figura 4. Estela 14 de Piedras Negras, Guatemala, $c a .761$ d.C.: a) Estela completa; b) detalle (fotografía Night Fire Films).
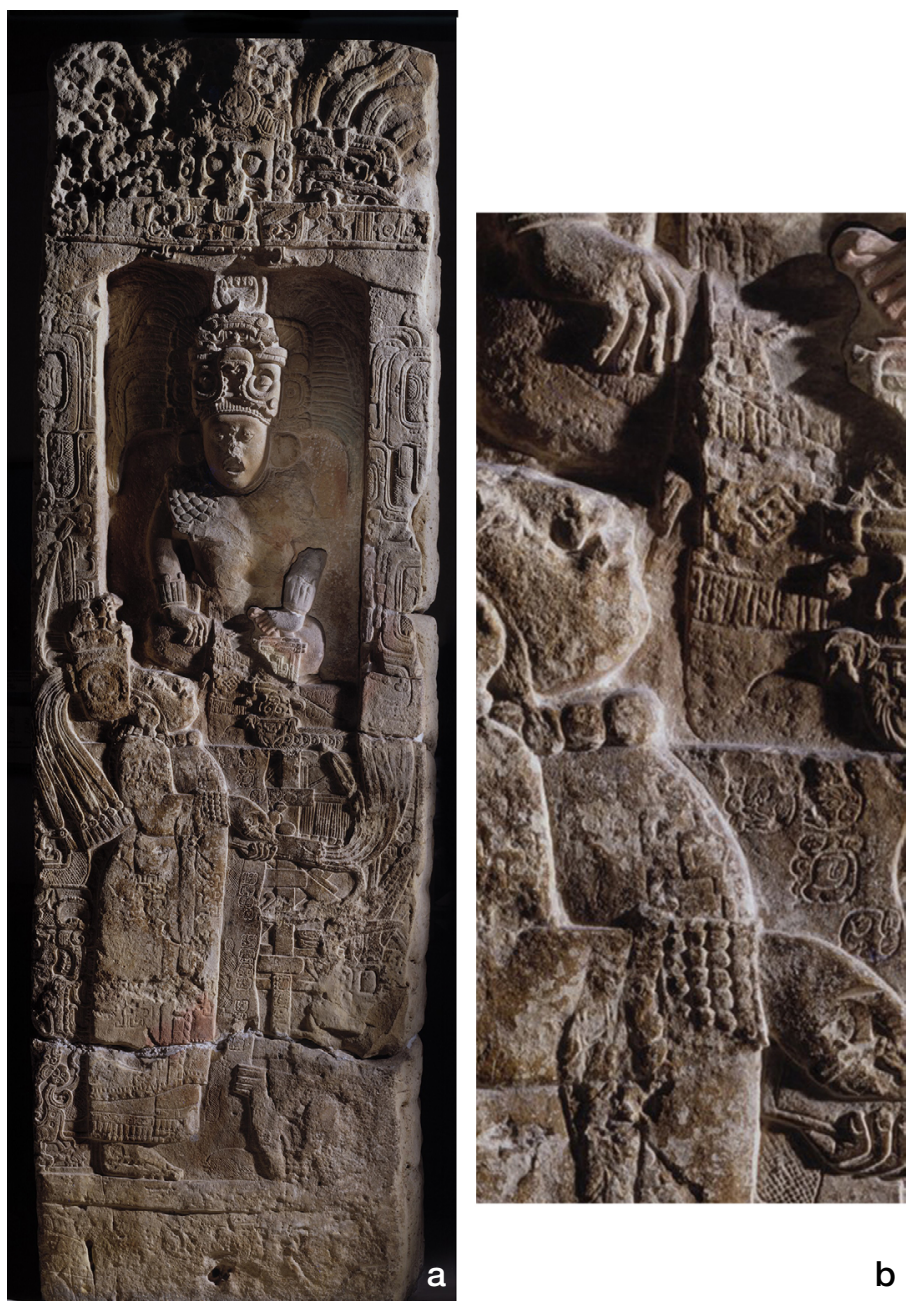

crean una ilusión tridimensional y transmiten la sensación del tacto. El sentido del tacto parece tan importante como la visión, tal vez más, ya que las personas están dentro de un espacio oscuro, iluminado por una antorcha, donde el sentido de la vista se reduce y el sentido del tacto se ve estimulado con respecto al resto de los sentidos.

La interacción entre los personajes y la atención a la tactilidad de las manos agarrando los objetos rituales aparecen en otras escenas, como en los monumentos de Piedras Negras. La Estela 14 de esta ciudad retrata al k'uhul ajaw K'inich Yo'nal Ahk sentado en unas andas adornadas con símbolos cosmológicos (Stone 1989; García Barrios 2015) (Figura 4). El rey participa en una ceremonia que renueva el mundo. Su madre se pone delante de él; es un personaje activo en este rito, y su presencia sanciona las acciones y la autoridad de su hijo. De nuevo, la interacción entre las personas es crucial. En realidad, la composición y el diseño general de este tipo de estelas requirió una solución para mostrar las interacciones entre el rey y otros nobles y también para presentar al rey frontalmente (O'Neil 2012: 71-79). El retrato de la reina madre, de pie en el suelo, frente al rey y mirándolo, también funciona como modelo para el observador, instando al espectador a mirar y a venerar al rey, quien 
está representado y encarnado en el monumento (es lo que se llama una composición abierta en Historia del Arte). Además, como vimos en el Dintel 24 de Yaxchilán, los artistas pusieron atención a las dos personas sosteniendo los objetos rituales: el rey sostiene una bolsa con incienso y su madre tiene un objeto emplumado, tal vez para derramar sangre. Sus dedos tocan y agarran los materiales con firmeza, acentuando la experiencia táctil de la narrativa pictórica y estimulando el sentido del tacto en el espectador, incluso si no se les permite tocar.

El tacto es también central en varias esculturas de Palenque (Chiapas, México). Por ejemplo, el panel tallado en piedra caliza del Templo XIV representa a la mujer noble Ixik Tz'akbu Ajaw que porta una efigie del dios K'awiil para mostrársela al rey K'inich Kan Bahlam II, quien baila ante ella ${ }^{4}$. También aquí, la interacción entre las dos personas es importante, y la efigie de la deidad es parte de su interacción. Ella sostiene la imagen en sus manos extendidas. El énfasis puesto en sus manos es crucial, pero no agarra la efigie, sino que está posada sobre su mano extendida. El envoltorio textil que cae de las manos de la mujer implica que la imagen estaba envuelta o empaquetada, como sucedió con muchas figuras de deidades del Área Maya y de toda Mesoamérica (Fitzsimmons 2009: 78-81; García Barrios y Valencia 2009). Desenrollar la efigie habría requerido la manipulación y el tacto, por lo menos para abrir y quitar la tela y luego para envolverla de nuevo. De hecho, hay menciones de acciones similares en las inscripciones de Palenque que narran rituales reales relacionados con el cuidado y la vestimenta de las efigies (Stuart y Stuart 2008: 167).

Estos tres ejemplos de esculturas de sitios diferentes son parte de un fenómeno más extenso en el arte maya que pone énfasis tanto en las interacciones como en el manejo y en la acción de tocar los objetos rituales que incluye esculturas de otros lugares como Tikal.

\section{La importancia de las manos en el arte y ritual maya}

Otro punto que sale de esta discusión es la importancia y la potencia de la mano en el arte y los contextos rituales. Vemos esto en las imágenes que ya explicamos, pero también está presente en el sistema de escritura maya. En particular, hay varios verbos que muestran gráficamente y destacan las manos como representantes de acciones que involucran más partes del cuerpo humano ${ }^{5}$. Por ejemplo, el glifo del verbo tzahk (conjurar), utilizado para la invocación de deidades y antepasados, es una mano agarrando un pez (Valencia y García Barrios 2010). Además, uno de los verbos para dedicar una estela o altar era k'al tuun (atar la piedra), mostrado con una piedra en una mano, tal vez porque la ceremonia implicaba el envoltorio de la estela con tela (Stuart 1996: 154-157) (Figura 5). El verbo k'al (atar o envolver), expresado gráficamente con una mano, también es usado en Palenque para remitir a la entronización del rey en la frase $k$ 'al sak huun (atar la cinta blanca), probablemente porque las ceremonias involucraron la atadura de una diadema real en la cabeza del rey. Aunque la ceremonia hubiera sido mucho más compleja, el énfasis está en la acción de la mano que ata la cinta.

\footnotetext{
4 Para más información sobre el dios K'awiil, véase la Tesis Doctoral de Rogelio Valencia (2016).

5 Erik Boot (s.f.) identificó 45 glifos (silabogramas y logrogramas) que involucran las manos humanas.
} 
Adicionalmente, hay ejemplos de objetos rituales con forma de manos, incluso algunos hechos de hueso, como los procedentes del Entierro 116 de Tikal. Los arqueólogos encontraron cinabrio en las palmas de estas manos que pudieron haber sido utilizadas como cucharas para aplicar cinabrio sobre el difunto en los preparativos funerarios. En otros ejemplos vemos la importancia de la mano del artista, por lo que sobre una espátula de la misma ofrenda está incisa la mano de un artista emergiendo desde otra dimensión (Figura 6). El pintor,

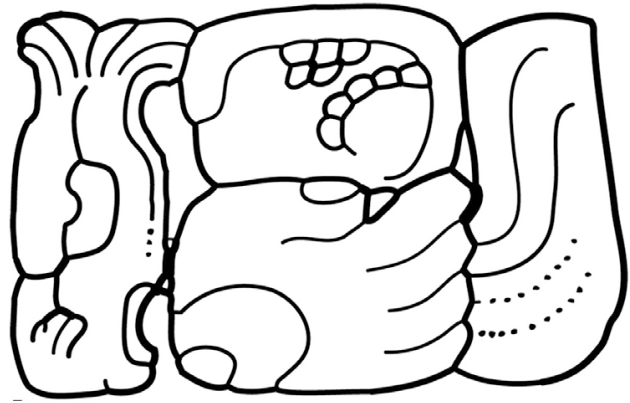

Figura 5. Jeroglífico B12 de la Estela 12 de Piedras Negras, Guatemala: $u$ k'al tuun, «su atadura de la piedra» (dibujo de Kevin Cain, INSIGHT, según Stuart y Graham 2003). que lleva un pincel entre los dedos, surge de una boca solar de ciempiés, el portal sobrenatural desde donde sale el sol diariamente y los antepasados renacen. Como Clemency Coggins (1975: 464) observó, esta imagen destaca el papel sobrenatural del artista maya. El trabajo de los artistas -que a menudo implica hacer visibles y materiales a las deidades- es la obra
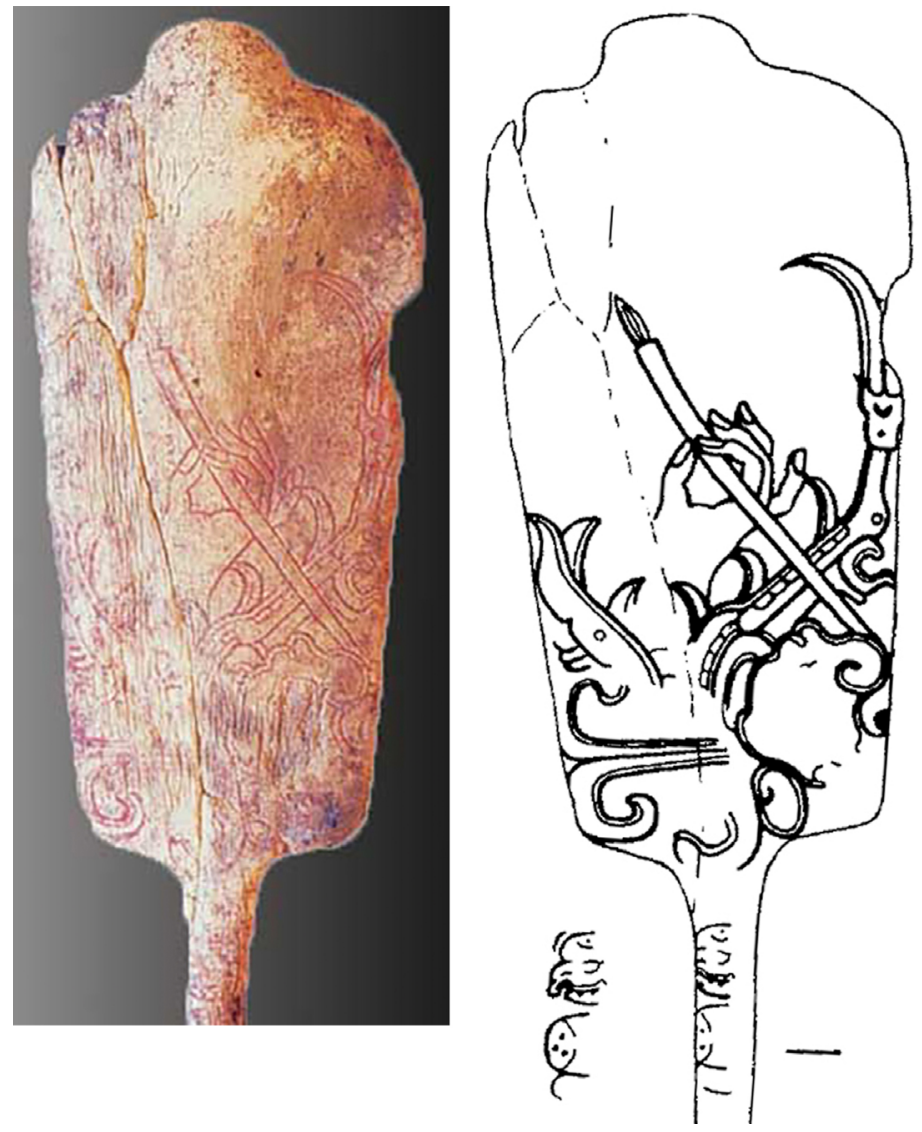

Figura 6. Tikal, Guatemala, Entierro 116: Hueso tallado con la mano de un artista saliendo del otro mundo, c. 734 d.C. $4 \mathrm{P}-4 \mathrm{P}-$ 113(30, 23), MT 52. a) Original (fotografía (C) Justin Kerr; b) dibujo (Annemarie Seuffert en Moholy-Nagy con Coe 2008: fig. 197a; cortesía de University of Pennsylvania Museum of Archaeology and Anthropology). 
divina, y la mano del artista emergiendo de otra dimensión acentúa ese significado. Esta espátula también podría haber sido usada para aplicar cinabrio sobre el difunto. En estos casos, las manos fabricadas realizan la acción significativa de preparar al rey para su resurrección.

Este énfasis en las manos no excluye la importancia de las otras partes del cuerpo, como la de la vista, que es clara y, por supuesto, la cabeza - tal y como han discutido Houston et al. (2006: 60)- es una de las partes más importantes del cuerpo. Pero las manos son especialmente activas durante el acción ritual. Es la mano la que enciende el fuego, envuelve y desenvuelve el textil y esparce el incienso-cuyo aroma inhala la nariz. El cuidado y la atención que los artistas mayas pusieron para comunicar el agarre casi eléctrico de las manos y los dedos sobre los objetos rituales, además del énfasis en las manos en los verbos para complejos rituales, sugieren la importancia de las manos y consecuentemente el sentido del tacto en la esfera ritual. No obstante, las manos actúan junto con las otras partes del cuerpo y las personas experimentan los rituales con sentidos múltiples, incluso la visión, oído, gusto y olfato, que juntos crean y aumentan la experiencia somática.

Adicionalmente, el sentido del tacto era un aspecto esencial en la manufactura de los objetos. Vemos huellas dactilares en muchas obras de arte maya. Son visibles en la superficie de las figurillas cerámicas del estilo Jaina, y las impresiones de los dedos del alfarero aparecen en la imagen de Rayos-X del fondo de la Vasija de los Once Dioses. Estas huellas dactilares son rastros del toque de los artistas que estaban modelando y refinando las formas de las figurillas y las vasijas. Y es así como nuevamente, destaca la importancia del sentido del tacto en el arte maya.

En definitiva, el sentido del tacto es claramente crucial en el arte y la práctica ritual maya, ya sea la acción de tocar del artista para realizar la obra, del usuario en la ejecución del ritual o del suplicante en la deposición del objeto en la tumba.

\section{Interacción con los objetos y monumentos: los huesos tallados de Tikal}

También podríamos ver la importancia del tacto, la interacción y el movimiento en el arte maya si estudiamos las estrategias de representación y composición que los escultores mayas usaban para guiar la participación directa con las imágenes y objetos, y así aumentar las experiencias con ellos. Dicha acción podría involucrar objetos u obras plásticas que exceden la escala humana, como una escultura monumental o un edificio, alrededor de los cuales el individuo se mueve. En este caso, el cuerpo está subyugado a la obra y la activa moviéndose alrededor. En contraste, una persona puede manipular con las manos los pequeños objetos, como una vasija cilíndrica de cerámica -que uno debe girar para ver la escena en total-o un implemento de hueso tallado. En la manipulación de los pequeños objetos, el cuerpo humano subyuga a la obra. En los dos casos, el movimiento y la interacción son cruciales para experimentar la obra y también para crear o participar en una experiencia ritual.

Un excelente estudio de caso es la ofrenda de huesos tallados depositada en el Entierro 116 de Tikal que se mencionó con anterioridad. Estos implementos -y la mayoría de los huesos tallados en el corpus maya- requieren la manipulación para revelar sus imágenes e inscripciones. Los textos incluyen el nombre del rey, Jasaw Chan K'awiil, y algunos podrían haber sido objetos personales que utilizó en vida, pero otros claramente fueron hechos para su muerte, sus preparaciones funerarias o 
su resurrección. Son de un tamaño suficiente como para sostenerlos en la mano y sin duda fueron utilizados para fines rituales. El cinabrio rojo sirvió para dos fines, para ser aplicado sobre el cuerpo del difunto, como se había mencionado anteriormente, y para resaltar las imágenes y los textos incisos.

En otro ensayo (O’Neil 2016), examiné la materialidad de estos huesos tallados, pensando en el manejo que los artistas hacían del hueso como un medio artístico. También investigué cómo las imágenes e inscripciones se refieren al contexto de la tumba, particularmente a la transformación, los viajes al inframundo u otro contacto sobrenatural. De hecho, la materialidad y la escala de estos huesos tallados eran aspectos esenciales de su creación, uso y percepción. Aunque los huesos están fragmentados y son tan frágiles que no pueden tocarse, si examinamos la integración de las imágenes y los textos con las formas físicas de los objetos y las formas de manejarlos, podemos entenderlos de maneras sorprendentemente nuevas. En particular, podríamos ver que los artistas ocultan ciertos elementos que luego emergen al momento de manipular el hueso. Efectivamente, el manejo de los objetos aporta una mayor visibilidad y comprensión, que es una metáfora de la experiencia ritual. Estas cualidades eran aspectos fundamentales de la fabricación de los huesos y de su atribuida potencia, ya fuese durante su creación o en el momento en que se depositaron en la tumba, donde sirvieron para establecer un entorno óptimo para el renacimiento del rey.

En algunos casos, los artesanos cortaron los extremos de los huesos largos para hacer tubos completos o reducidos a la mitad. Tallaron las superficies con imágenes y textos, envolviéndolos alrededor del eje del tubo óseo. Lo más común es que los hicieran en pares que llevan imágenes en espejo y textos paralelos, interrelacionándose con la forma natural del animal del que provienen. Por ejemplo, un par de huesos (MT55A y 55B) están labrados con las imágenes en espejo del dios del maíz dentro de un cartucho que él agarra con la mano (Figura 7). El cartucho está cubierto con nenúfares, sugiriendo que está en la superficie del agua. Abajo está el dios Pax de cuya cabeza y boca surgen emanaciones que se extienden hacia abajo y se envuelven alrededor de los ejes. Por eso, uno debe girarlos para ver las imágenes completas. Se puede decir que el artista utilizaba el material de la mejor forma posible, pero es importante reconocer que la envoltura y el giro necesario para revelar la imagen produzcan una metáfora de la experiencia de lo sobrenatural, porque la totalidad no puede ser percibida de un vistazo. La visión humana es limitada, pero con la acción ritual, uno puede vislumbrar lo sobrenatural.

En otros casos, los artistas tallaron narrativas multi-figurativas, como las siete escenas con canoa, que refieren los viajes de transformación y el contacto entre mundos. Entre ellas se encuentran dos huesos (Figura 8), MT51A y 51B, con escenas de Chaahk, dios de la lluvia, pescando. Aparece en las canoas y el agua, donde captura los peces con sus manos 6 . Son animaciones del verbo tzahk, «conjurar,» cuya forma gráfica es una mano que sostiene un pez, utilizado para la invocación de deidades y antepasados. Como observó Taube (2004: 76), el verbo tzahk en maya yucateco de la época colonial puede significar tanto pescar como conjurar las nubes y el viento. Entonces, el significado de tzahk es agarrar algo de otra dimensión. Las imágenes y los textos se envuelven alrededor de la superficie curvada de los tubos óseos, y uno tiene que girarlos para leerlos y que se produzca la revelación.

\footnotetext{
Escenas similares con el dios Chaahk pescando aparecen en otros medios como la escultura y los códices desde el periodo Preclásico al Posclásico (García Barrios 2009: 351-361).
} 

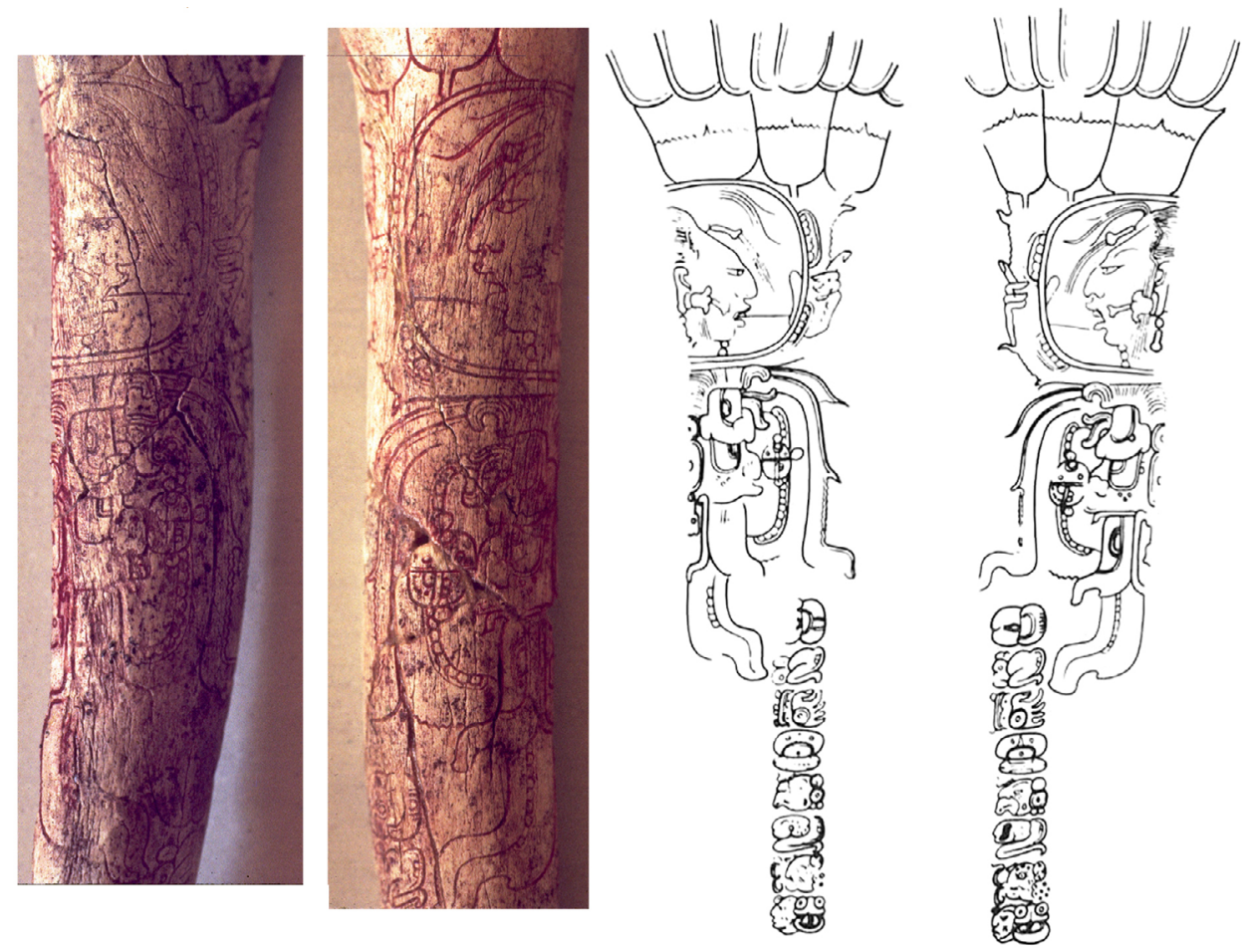

Figura 7. Tikal, Guatemala, Entierro 116: Huesos tallados con dios del maíz en cartucho, $c$. 734 d.C. 4P-113(10)/2, MT55A, 4P-113(4)/2, MT55B. a) Detalles del original (fotografías de Linda Schele (CDavid Schele); b) dibujos (Annemarie Seuffert, en Trik 1963: figs. 1, 2).

Las composiciones de otro par de huesos, MT39B y 39A (que comentamos arriba, ver Figura 2), producen un efecto diferente. Cada uno tiene una imagen de un cautivo atado, que, de manera similar a los otros pares, llevan imágenes en espejo y textos paralelos. Hay breves inscripciones cerca del cuerpo de cada cautivo, y hay inscripciones más largas en las partes posteriores ${ }^{7}$. Estos huesos también tienen que ser manipulados para apreciarlos en su totalidad, para ver la imagen y el texto corto debe girarse ligeramente, y para ver el texto en la parte posterior hay que voltearlo. Este diseño es análogo al de una estela que muestra una persona de pie en un lado y las inscripciones en el otro. Sin embargo, tanto la forma como el significado están invertidos. Las estelas son monumentales, son de piedra y retratan los reyes como guerreros vencedores, pero los huesos son miniaturas, el soporte proviene de un cuerpo descarnado, y retratan cautivos. Además, como observó Stuart (1985: 98), en muchas lenguas mayas la palabra para prisionero es baak, la misma que define al hueso. El hecho de que este prisionero fuera tallado en hueso es porque fue importante y significativo, y se realizó con la intención de producir una fusión de la imagen representada con el material. Aunque probablemente el hueso es de jaguar -y no humano- el medio es parte del mensaje, porque el hueso descarnado se alinea con el

\footnotetext{
Martin y Grube (2008: 111) demuestran que los textos en las partes anteriores identifican el cautivo como un señor de Hixil que es umam -el «nieto» o «abuelo»- de «Tierra Partida,» un señor divino de Calakmul, y el texto en la parte posterior «parece describir una batalla en noviembre de 695 d.C., nombrándolo vencedor».
} 

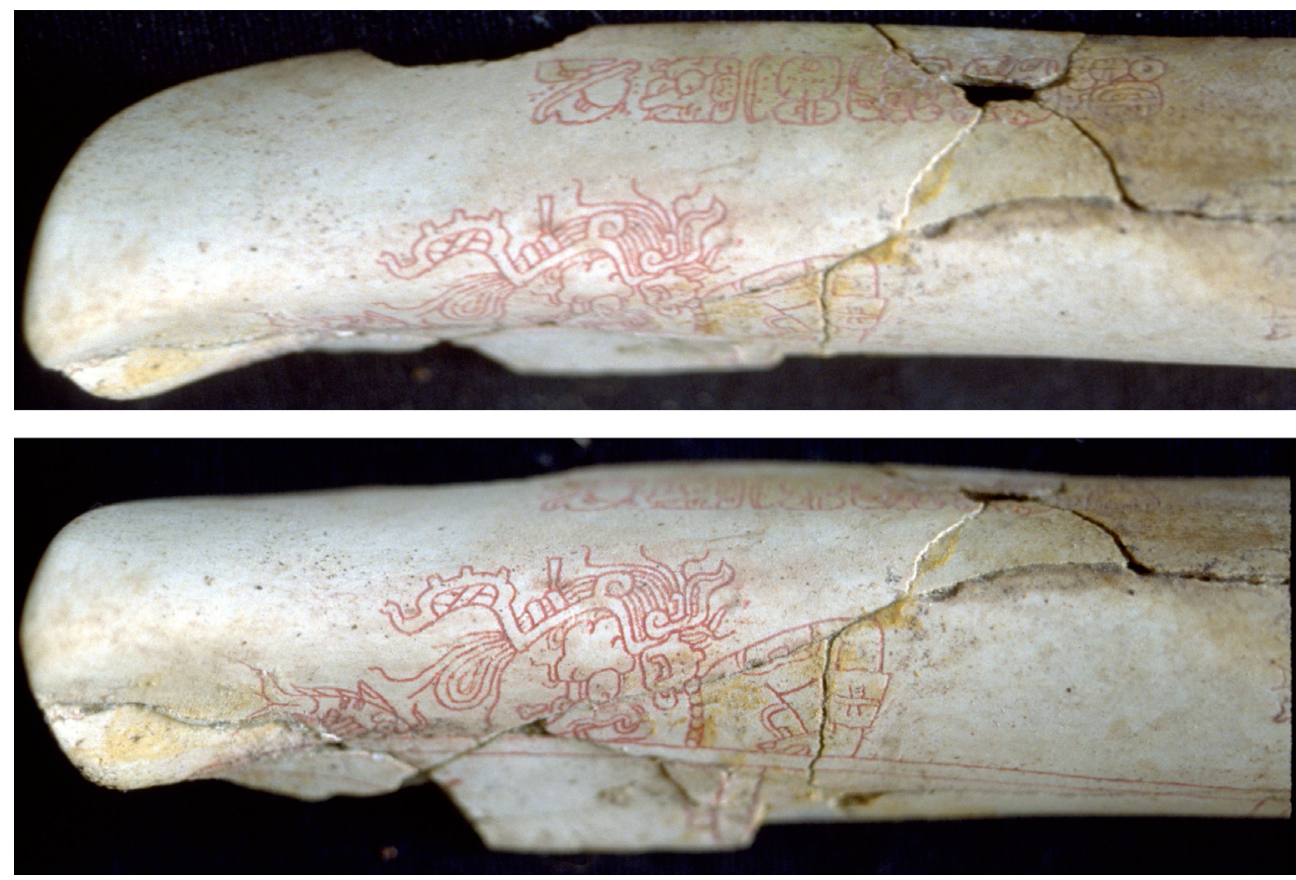

Figura 8. Tikal, Guatemala, Entierro 116: Hueso tallado con escena del dios Chaahk pescando, c. 734 d.C. 4P-113(63). MT 51A. L. 25,9 cm (fotografías de Linda Schele, 77020, 77021 (CDavid Schele).

cautivo desnudo, y también quizás señala su estado inminente de ser sacrificado e incluso descarnado. Finalmente, una estela monumental requiere que la persona camine alrededor, pero uno puede manipular estos huesos con un simple giro manual; de hecho, la manipulación tal vez era otra manera para controlar y humillar el cautivo.

En resumen, vemos la importancia de la interacción y del sentido del tacto en la experiencia de estos implementos ceremoniales, pero también es claro que el sentido del tacto es complementario al sentido de la vista. Pensando en la materialidad, tanto la vista como el tacto comunican que el material es hueso debido a las formas diagnósticas de los huesos, los colores y texturas de sus superficies. Además, al girar el objeto las manos ayudan a la persona a seguir viendo la imagen, pero los ojos perciben el contenido de la imagen y el texto. Funcionan juntos y seguramente operan en un entorno en que otros sentidos, como el olfato, son estimulados. Por eso, se hace evidente que los estudios de iconografía deberían tomar en cuenta las maneras de percibir y experimentar las imágenes y los objetos.

\section{Interacción con los monumentos y objetos: las esculturas de Piedras Negras}

Otro excelente estudio de caso es la escultura monumental de Piedras Negras, que difiere del ejemplo anterior porque las obras son más grandes que el cuerpo humano. Los gobernantes de Piedras Negras - del reino Yokib- erigieron estelas, altares y paneles de piedra caliza en medio de los altos templos, las extensas plazas y las 
calzadas del sitio. Estuvieron tallados con textos jeroglíficos e imágenes de gobernantes acompañados por miembros de la familia, consejeros, cautivos, antepasados y deidades. Pocas esculturas permanecen en el sitio arqueológico. Unas están en el Museo Nacional de Arqueología y Etnología de Guatemala, mientras que otras fueron cortadas, fragmentadas y robadas por saqueadores, y ahora están esparcidas por todo el mundo en museos y colecciones privadas (Stuart y Graham 2003; O'Neil 2012: 189-211). Sin embargo, para entender verdaderamente los monumentos, necesitamos mirarlos en sus contextos antiguos y preguntar cómo funcionaban como obras materiales. Cuando reconstruimos estos contextos, vemos que las formas físicas de las esculturas de Piedras Negras invitaban a las personas a interactuar con ellas y moverse alrededor de los monumentos.

Las estelas más antiguas fueron talladas sólo en sus caras frontales, con el rey como protagonista. A partir del reinado del Gobernante 2 (639-686 d.C.), y continuando en reinos posteriores, los escultores utilizaron los otros lados de las estelas, parte posterior, costados y cantos superiores para tallar los textos y las imágenes, incluyendo representaciones de esposas, madres, hombres de la corte y gobernadores regionales (O'Neil 2012: 71-79). Usaron estas composiciones para retratar figuras interactuando en el espacio, lo que permitió destacar al rey y al mismo tiempo mostrar interacciones sociales entre este rey y los otros nobles (ver Figura 4). Estos aspectos de las composiciones de las esculturas y sus relaciones con el espacio ambiental y los espectadores potenciales se corresponden con la importancia cultural y social del testimonio y la demostración de las relaciones sociales en la cultura de la corte maya (Houston et al. 2006: 172-173). En una serie de esculturas de Piedras Negras, mujeres y hombres son retratados como testigos de los gobernantes realizando ceremonias y, a través de estas interrelaciones, se muestran conectados con el poder.

La presencia de las imágenes en múltiples lados podría haber guiado a la gente para moverse alrededor del monumento, para experimentar la tridimensionalidad y las relaciones sociales presentadas. Por otra parte, las figuras secundarias, representadas de pie en el suelo al mismo nivel que los espectadores, podrían haber actuado como mediadores entre los gobernantes encarnados en los monumentos y las personas que los vieron. Además, la importancia del testimonio puede aplicarse no sólo a los personajes representados en las esculturas, sino también a la experiencia de estas esculturas. Cuando las personas interactuaban con las estelas y sus imágenes vitales se convertían en testigos de las ceremonias retratadas y se integraban en estas relaciones sociales. En este caso, la vista y el movimiento corporal del suplicante funcionan juntos para crear una experiencia ritual y social.

Aún más notable es la proximidad entre los cautivos en estados vulnerables cerca de los pies de los reyes guerreros retratados en los monumentos. En las estelas de los siglos VII y VIII, los cautivos aparecen sentados o arrodillados en un nivel inferior que el rey, que era congruente con el espacio del espectador (O’Neil 2012: 81-84); esta composición destaca la proximidad y la asimilación del espectador y el cautivo. Por ejemplo, en la cara frontal de la Estela 8, que muestra una enorme imagen de K'inich Yo'nal Ahk II vestido como guerrero, los dos cautivos se arrodillan en un escalón debajo del gobernante (Figura 9). De hecho, es el mismo nivel en que se encuentra el observador. Los distintos niveles en la imagen -especialmente en relación con su espacio ambiental- enfatizan aún más la asimilación de una persona viviente a los cautivos humillados y la distancia del gobernante que los domina. 
La colocación de los textos en varios lados de los monumentos también revela cómo guiaban la interacción. Por ejemplo, los textos están tallados en tres lados de la Estela 3 , y para verlos o leerlos una persona debe moverse alrededor de la estela. Los textos en los lados del monumento y en la parte posterior narran las celebraciones paralelas del decimocuarto $k^{\prime}$ atun por el rey y la reina, K'inich Yo'nal Ahk II e Ixik K'atun Ajaw, indicando que desempeñaron ceremonias complementarias en la renovación del tiempo. La lectura de los textos laterales invita al espectador a rodear el monumento en el sentido contrario a las agujas del reloj. Se observa este patrón en la mayoría de las esculturas de los reinados de los Gobernadores 1 a 7 (O'Neil 2012: 91), incluso en la Estela 8 del Gobernante 3 (Figura 10). El monumento que guía la circunvalación más explícitamente es el Altar 1 de K'inich Yo'nal Ahk II, que fue instalado en la plaza justo debajo de sus estelas. Es una mesa circular sobre tres soportes, y los textos están tallados en la parte exterior y en los soportes, por lo que se tiene que rodear el altar al menos dos veces para seguir el texto (Figura 11). Por eso es comparable a las estelas, pero el movimiento circular es más pronunciado debido a los múltiples circuitos.

El contenido de los textos relata las ceremonias calendáricas, consideradas como las celebraciones diseñadas para renovar el mundo. El Altar 1 narra múltiples aniversarios calendáricos durante más de 5125 años e incluye la fecha 4 Ahaw 8 Kumk'u,

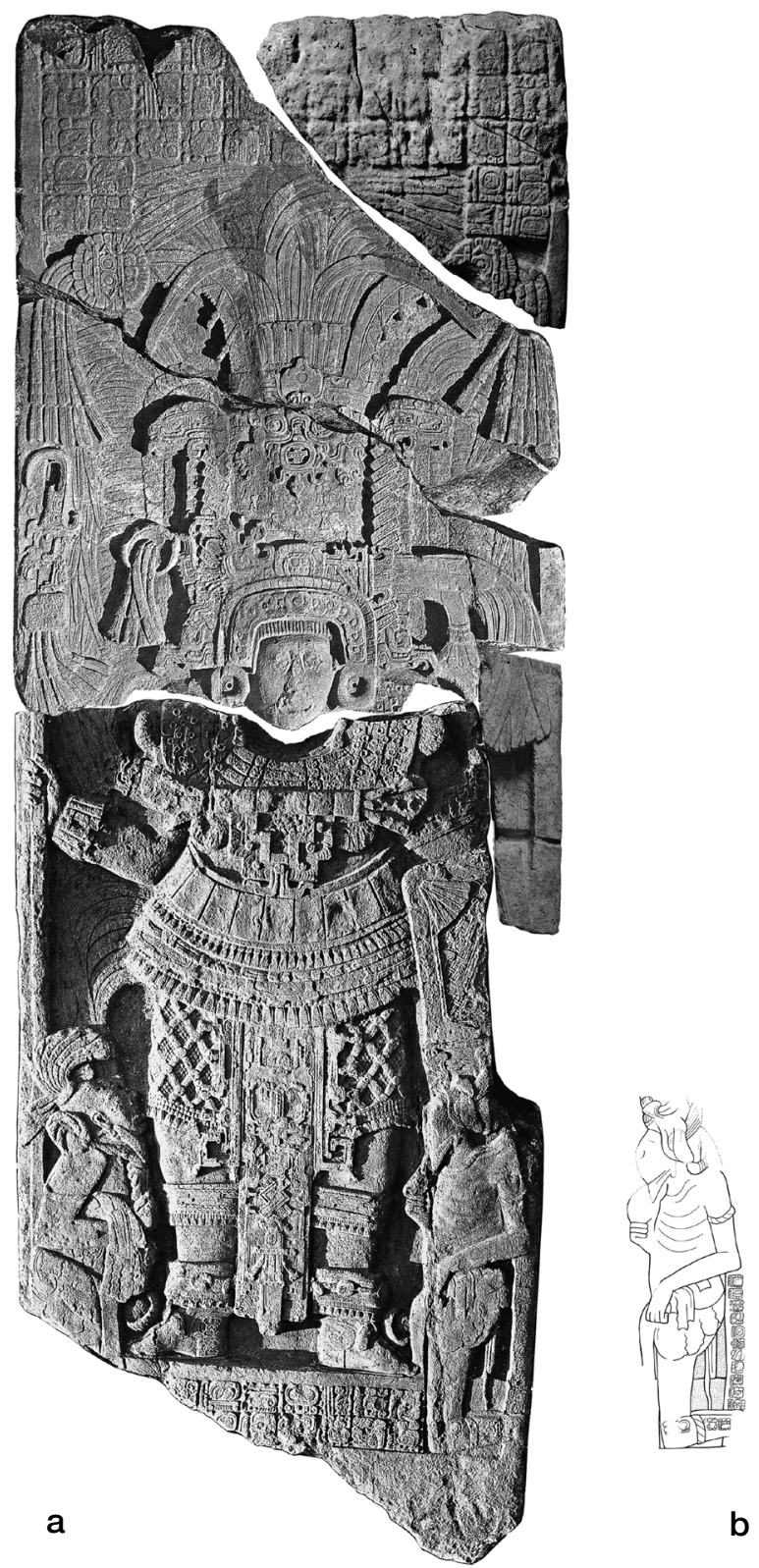

Figura 9. Estela 8, Piedras Negras, Guatemala, $c a$. 724-29 d.C. a) Composición del original (Maler 1901: plate XVII); b) dibujo de detalle de la estela (Stuart y Graham 2003: 43; cortesía del President and Fellows of Harvard College). 


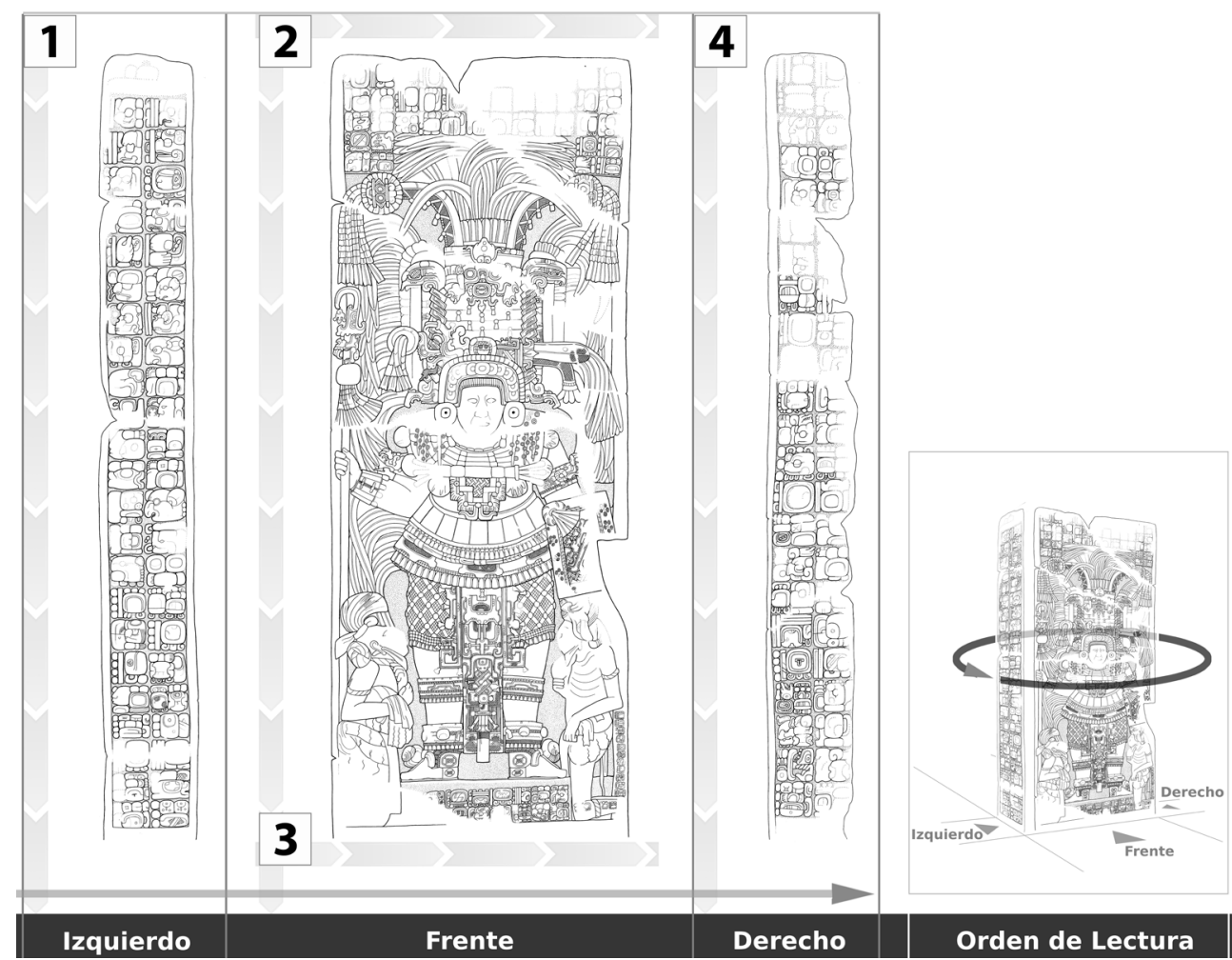

Figura 10. Estela 8, Piedras Negras, Guatemala, ca. 724-729 d.C., con flechas que muestran la dirección del orden de lectura (diagrama de Kevin Cain, INSIGHT, según dibujos de Stuart y Graham 2003: 43. Cortesía del President and Fellows of Harvard College).

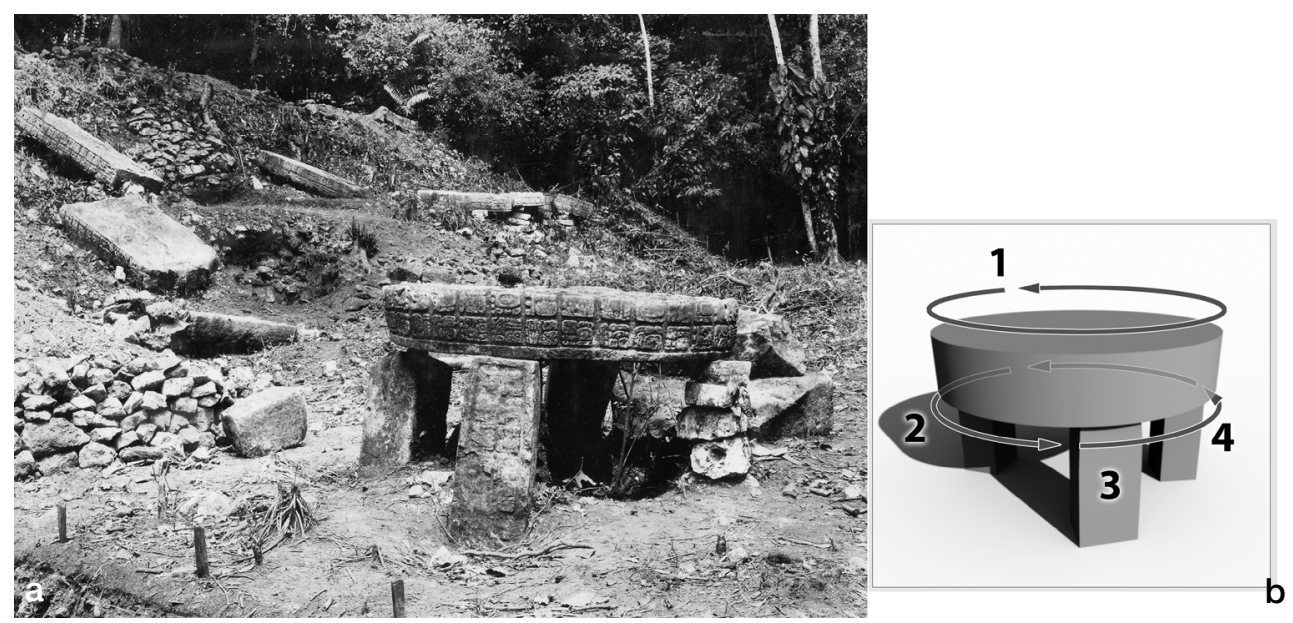

Figura 11. Altar 1, Piedras Negras, Guatemala, 692 d.C. a) Fotografía ca. 1933, cortesía de Cortesía de University of Pennsylvania Museum of Archaeology and Anthropology, Image \#175939. b) Diagrama de orden de lectura (Kevin Cain, INSIGHT). 
el principio del ciclo y el momento paradigmático de la renovación mundial (O'Neil 2012: 93-94). Esta cuenta de los ciclos temporales se correlaciona con el formato físico del monumento y el camino que lo rodea. En particular, la circunvalación es una forma de procesión relacionada con la renovación del mundo. Además, la frase más comúnmente usada para la dedicación de monumentos en Piedras Negras era $k^{\prime} a l$ tuun (atar la piedra). David Stuart ha propuesto que el acto de enlazar correspondió al envoltorio de las estelas con tela (1996: 154-157). Sugiero que también la lectura de los textos en forma circular alrededor del monumento era otro tipo de enlazamiento o atado de la piedra, acción que formó parte de la dedicación del monumento y de la renovación del tiempo.

Pero los monumentos, tan polivalentes como eran, cambiaban inevitablemente con el tiempo. Cada gobernante dedicó varias estelas en múltiples aniversarios del calendario durante su vida, y las estelas y altares permanecieron de pie después de que murieron y continuaron siendo vitales y relevantes. Sin embargo, inevitablemente cambiaron cuando la persona murió y se convirtió en un antepasado. De hecho, algunas modificaciones marcan este cambio. Los rostros - ojos, narices y bocas- de muchas de las figuras retratadas en las estelas fueron picoteadas por medio de percusiones indirectas, quizás para impedir que la imagen viera o respirara, o para desactivar o neutralizar a la poderosa entidad (Houston y Stuart 1998; Just 2005; Mesick 2006). La acción del picoteo fue el procedimiento operativo, pero las marcas en las caras permanecieron visibles y señalaron circunstancias pasadas, señalando así el cambio de gobernante a antepasado, y de una transformación análoga de los monumentos. También las áreas picoteadas indicaban la acción que involucraba el trabajo de la mano, ya que la superficie había sido cambiada por la acción de unas manos usando herramientas. Por lo tanto, de esta otra manera, las cicatrices podrían haber estimulado el sentido del tacto a los que estaban mirando. A pesar de estos cambios, las modificaciones no desactivaron completamente los monumentos, que siguieron siendo vitales, actuales y relevantes. De hecho, quedaron visibles y se convirtieron en elementos para la comunicación con personajes del pasado: las esculturas más nuevas repetían motivos y formas de sus predecesoras más antiguas, y estaban orientadas hacia dichos ancestros, dando a los espectadores la oportunidad de ver y experimentar las obras de múltiples generaciones.

En todos estos contextos, se evidencia la experiencia cambiante de las esculturas de Piedras Negras, tanto alrededor de las esculturas individuales, como de múltiples esculturas conjuntas. Además, a través de estas imágenes y de las vías procesionales que las conectan, los mayas integraron los diálogos históricos y la conmemoración ancestral en el paisaje.

\section{Conclusiones}

Al observar las imágenes y los textos en relación con su soporte material y su contexto físico se revelan las complejidades de estas potentes obras. Del mismo modo, una gran parte del arte maya sirve para involucrar al espectador o usuario, invitándolo a manejar el objeto, acercarse y moverse más lejos, participar en el espacio adentro y afuera de la imagen, y entrar en comunicación con las personas representadas, así como con la esencia de las imágenes y los objetos. El aislamiento de las imágenes en un estudio iconográfico puede ayudar a identificarlas, pero hay que volver a los ob- 
jetos y analizar sus propiedades físicas y las posibles interacciones que las personas podrían haber tenido. El arte maya es fundamentalmente una tradición interactiva, en donde el tacto y el movimiento son esenciales. Las obras de arte en esta cultura no fueron elaboradas para ser vistas únicamente, sino también para ser usadas y experimentadas.

\section{Referencias}

Boot, Erik. n.d. «The Human Hand in Classic Maya Hieroglyphic Writing». Mesoweb. http:// www.mesoweb.com/features/boot/human_hand.pdf.

Coe, William R. 1990. Excavations in the Great Plaza, North Terrace, and North Acropolis of Tikal. Tikal Report 14, Vol. II. Filadelfia: University of Pennsylvania Museum of Archaeology and Anthropology.

Coggins, Clemency Ch. 1975. Painting and Drawing Styles at Tikal: An Historical and Iconographic Reconstruction. Tesis de Doctorado, Fine Arts, Harvard University.

Edwards, Elizabeth. 1999. «Photographs as Objects of Memory», en Material Memories: Design and Evocation, Marius Kwint, Christopher Breward y Jeremy Aynsley, eds. pp. 221-236. Oxford: Berg.

Fitzsimmons, James L. 2009. Death and the Classic Maya Kings. Austin: University of Texas Press.

García Barrios, Ana. 2009. Chaahk, el dios de la lluvia, en el periodo Clásico maya: aspectos religiosos y políticos. Tesis de Doctorado, Facultad de Geografía e Historia, Universidad Complutense de Madrid.

- 2015. «El mito del diluvio en las ceremonias de entronización de los gobernantes mayas. Agentes responsables de la decapitación del saurio y nuevas fundaciones». Estudios de Cultura Maya 45: 9-48.

García Barrios, Ana y Rogelio Valencia Rivera. 2009. «A cuestas con sus dioses. Implicaciones religiosas de las migraciones mayas», en Diásporas, migraciones y exilios en el mundo maya, Mario Humberto Ruz, Joan García Targa y Andrés Ciudad, eds., pp. 79-101. Mérida: Sociedad Española de Estudios Mayas, Centro Peninsular en Humanidades y Ciencias Sociales.

Houston, Stephen D. y David Stuart. 1998. «The Ancient Maya Self: Personhood and Portraiture in the Classic Period». RES: Anthropology and Aesthetics 33: 73-101.

Houston, Stephen D. y Karl A. Taube. 2000. «An Archaeology of the Senses: Perception and Cultural Expression in Ancient Mesoamerica». Cambridge Archaeological Journal 10 (2): 261-294.

Houston, Stephen D., David Stuart y Karl A. Taube. 2006. The Memory of Bones: Body, Being, and Experience among the Classic Maya. Austin: University of Texas Press.

Just, Bryan. 2005. «Modifications of Ancient Maya Sculpture». RES: Anthropology and Aesthetics 48: 69-82.

Maler, Teobert. 1901. Researches in the Central Portion of the Usumatsintla Valley: Report of Explorations for the Museum, 1898-1900. Memoirs of the Peabody Museum of American Archaeology and Ethnology II-1. Cambridge: Harvard University.

Martin, Simon y Nikolai Grube. 2008. Chronicle of the Maya Kings and Queens: Deciphering the Dynasties of the Ancient Maya. $2^{\mathrm{a}}$ edición revisada. Nueva York: Thames and Hudson.

Merleau-Ponty, Maurice. 2002 (1945). Phenomenology of Perception. Londres y Nueva York: Routledge Classics. 
Mesick, Cassandra L. 2006. The Modification of Maya Monuments: Towards a Local Theory of Sculptural Ontology. Tesis de Maestría. Brown University.

Meskell, Lynn. 2004. «Divine Things», en Rethinking Materiality: The Engagement of Mind with the Material World, Elizabeth DeMarrais, Chris Gosden y Colin Renfrew, eds., pp. 249-259. Cambridge: MacDonald Institute Monographs.

Moholy-Nagy, Hattula con William R. Coe. 2008. The Artifacts of Tikal: Ornamental and Ceremonial Artifacts and Unworked Material. Tikal Report 27A. Filadelfia: University of Pennsylvania Museum of Archaeology and Anthropology.

O’Neil, Megan E. 2012. Engaging Ancient Maya Sculpture at Piedras Negras, Guatemala. Norman: University of Oklahoma Press.

- 2016. «Nuevas perspectivas sobre los huesos tallados del Entierro 116 de Tikal», en XXIX Simposio de Investigaciones Arqueológicas en Guatemala 2015, Bárbara Arroyo, Luis Méndez y Gloria Ajú, eds., Tomo II, pp. 741-752. Guatemala: Museo Nacional de Arqueología y Etnología.

Stone, Andrea. 1989. «Disconnection, foreign insignia and political expansion: Teotihuacán and the warrior stelae of Piedras Negras», en Mesoamerica After the Decline of Teotihuacán, A.D. 700-900, Richard Diehl y Janet C. Berlo, eds., pp. 153-172. Washington, D.C.: Dumbarton Oaks Research Library and Collection.

Stuart, David. 1985. «The 'Count of Captives' Epithet in Classic Maya Writing», en Fifth Palenque Round Table, 1983, Virginia M. Fields, ed., pp. 97-101. San Francisco: PreColumbian Art Research Institute.

- 1996. «Kings of Stone: A Consideration of Stelae in Ancient Maya Ritual and Representation». RES: Anthropology and Aesthetics 29/30: 148-171.

Stuart, David e Ian Graham. 2003. Corpus of Maya Hieroglyphic Inscriptions, Vol. 9, Part 1, Piedras Negras. Cambridge: Peabody Museum of Archaeology and Ethnology, Harvard University.

Stuart, David y George Stuart. 2008. Palenque: Eternal City of the Maya. Londres: Thames and Hudson.

Taube, Karl A. 2004. «Flower Mountain: Concepts of Life, Beauty, and Paradise among the Classic Maya». RES: Anthropology and Aesthetics 45: 69-98.

Trik, Aubrey S. 1963. «The Splendid Tomb of Temple I at Tikal, Guatemala». Expedition 6 (1): 2-19.

Valencia Rivera, Rogelio. 2016. El rayo, la abundancia y la realeza. Análisis de la naturaleza del dios K'awiil en la cultura y la religión mayas. Tesis de Doctorado, Facultad de Geografía e Historia, Universidad Complutense de Madrid.

Valencia Rivera, Rogelio y Ana García Barrios. 2010. «Rituales de Invocación al Dios K'awiil», en El ritual en el mundo maya: de lo privado a lo público, Andrés Ciudad, $\mathrm{M}^{\mathrm{a}}$ Josefa Iglesias y Miguel Sorroche, eds., pp. 235-261. Madrid: Sociedad Española de Estudios Mayas.

Van Dyke, Ruth. 2012. «Imagined Narratives: Sensory Lives in the Chacoan Southwest», en Making Senses of the Past: Toward a Sensory Archaeology, Jo Day, ed., pp. 390-408. Occasional Paper 40. Carbondale: Center for Archaeological Investigations, Southern Illinois University. 